\title{
The estimation of aboveground biomass and nutrient pools of understorey plants in closed Norway spruce forests and on clearcuts
}

\author{
Steffi Heinrichs • Markus Bernhardt-Römermann • \\ Wolfgang Schmidt
}

Received: 30 June 2009/Revised: 23 December 2009/ Accepted: 5 February 2010/Published online: 5 March 2010

(C) The Author(s) 2010. This article is published with open access at Springerlink.com

\begin{abstract}
The estimation model PhytoCalc allows a nondestructive quantification of dry weight and nutrient pools of understorey plants in forests by using the relationship between species biomass, cover and mean shoot length. The model has been validated with independent samples in several German forest types and can be a useful tool in forest monitoring. However, in open areas within forests (e.g. clearcuts), the current model version underestimates biomass and produces unreliable nutrient pool estimations. Thus, tissue density, as approximated by leaf dry matter content (LDMC), is systematically higher under high light compared to low light conditions. We demonstrate that the ratio of LDMC under clearcut conditions to LDMC under forest conditions can be used to adjust the PhytoCalc model to clearcut conditions. We investigated the LDMC ratio of five exemplary species commonly occurring on clearcuts. Integrating the square of the ratio as a correction factor
\end{abstract}

Communicated by C. Ammer.

Electronic supplementary material The online version of this article (doi:10.1007/s10342-010-0362-7) contains supplementary material, which is available to authorized users.

S. Heinrichs $(\square) \cdot$ W. Schmidt

Department Silviculture and Forest Ecology of the Temperate

Zones, Faculty of Forest Sciences and Forest Ecology,

Georg-August University Göttingen, Büsgenweg 1,

37077 Göttingen, Germany

e-mail: sheinri@gwdg.de

W. Schmidt

e-mail: wschmid1@gwdg.de

\section{Bernhardt-Römermann}

Department of Ecology and Geobotany, Goethe-Universität

Frankfurt am Main, Siesmayerstraße 70 B,

60323 Frankfurt am Main, Germany

e-mail: Bernhardt-m@bio.uni-franfurt.de improved estimates of biomass to more than $70 \%$ fit between observations and predictions. Results also suggest this ratio can be used to correct nutrient concentrations modelled in PhytoCalc, which tend to be overestimated in clearcuts. As morphological groups of plant species exhibit significantly different ratios, we advise using group-specific correction factors for clearcut adjustments in the future.

Keywords PhytoCalc .

Leaf dry matter content (LDMC) - Nutrient concentration · Plant morphological groups

\section{Introduction}

With $1-2 \%$, the contribution of the understorey vegetation to aboveground biomass in forest ecosystems is relatively low compared to the tree layer (Bolte et al. 2004; Gilliam 2007). However, as herbaceous plants have up to threefold higher nutrient concentrations than trees, the importance of the understorey vegetation for nutrient cycling is overproportionate to its biomass (Blank et al. 1980; Yarie 1980; Rodenkirchen 1995; Mrotzek 1998; Bolte et al. 2004; Muller 2003). Its importance even increases in disturbed systems such as clearcuts or windthrows, where the understorey vegetation becomes the most important ecosystem component in terms of primary production and nutrient uptake. Through changes in species composition, nutrient concentration and growth, the understorey vegetation can function as an important nutrient sink (Marks and Bormann 1972; Boring et al. 1981; Outcalt and White 1981; Fahey et al. 1991; Mellert et al. 1998; Bartsch 2000). However, the quantification of biomass and nutrient pools is very time-consuming and cost-intensive, as mainly destructive 
harvesting methods with many replicates are used. Furthermore, this approach cannot be used in protected areas and is not repeatable on the same plot, making such methods unfeasible for biomonitoring and permanent plot studies. Non-destructive estimation methods that use relationships between biomass and vegetation cover have been devised for several vegetation types (Siccama et al. 1970; Röttgermann et al. 2000; Muukkonen et al. 2006), but do not regard nutrient pools. Thus, intensive monitoring programs such as the European Level-II-network (Schulze et al. 2000; De Vries et al. 2003; Seidling 2005) have so far considered understorey vegetation only in terms of its indicator quality and contribution to forest biodiversity.

Enhancing an earlier approach by Kellomäki (1974), the PhytoCalc model was developed (Bolte 1999, 2006; Bolte et al. 2002) to estimate aboveground biomass and nutrient pools of the forest understorey based on cover and mean shoot length of plant species. Data from biomass harvests of 46 widespread species of beech, oak and Scots pine forests of north-eastern Germany and the low mountain ranges provided the basis for this model. Species data were aggregated into 13 morphological growth groups (main groups: herbs, graminoids, ferns, small shrubs, dwarf shrubs, mosses). For each growth group, non-linear regressions were developed to describe the relationship between aboveground biomass, species coverage and mean shoot length. In addition, during the model development species were joined to different element groups; these groups are characterised by similar nutrient concentrations within the aboveground plant organs, and consider as well the species morphology, taxonomy and site characteristics. Average nutrient concentrations of each element group were used to predict nutrient pools of plants per area by multiplicatively linking the estimated dry weight and the nutrient concentration.

PhytoCalc has been successfully validated on independent measurements in several German forest ecosystems (Mölder et al. 2008; Schulze et al. 2009). Mölder et al. (2008) found that predicted values differed by less than $10 \%$ from harvested dry weights in Hainich National Park (Thuringia), an area with broad deciduous forests rich in tree species. PhytoCalc is thus suited to measure biomass and nutrient pools of understorey vegetation in forest monitoring (Bolte et al. 2004; BMELV 2006; Bolte 2006; Schulze et al. 2009).

In disturbed areas with high irradiance levels, the model so far yielded inadequate results. Klinck and Fröhlich (2009) found that PhytoCalc strongly underestimated the aboveground biomass in small clearcuts of Norway spruce stands. This would suggest the establishment of a new model under these open field conditions which would require intensive harvesting operations. A shortcut solution could be the comprehension of tissue density. It is well known that plants in open areas form denser tissues (Meziane and Shipley 1999; Schulze et al. 2002) than in closed forests. Tissue density can be expressed by the leaf dry matter content (LDMC; Garnier and Laurent 1994; Wilson et al. 1999; Westoby et al. 2002); a plant trait easy to measure using only a small number of plant individuals (Cornelissen et al. 2003). In this study, we compare LDMC of understorey plant species under closed canopy and in 4year-old clearcuts and demonstrate that the LMDC ratio can be used to correct the results of PhytoCalc in order to achieve reliable aboveground biomass estimations with estimation deviations close to those of the initial PhytoCalc model (Bolte 1999; Schulze et al. 2009). We investigated Agrostis capillaris, Deschampsia flexuosa, Digitalis purpurea, Epilobium angustifolium and Rubus idaeus as five frequent species in Norway spruce forests of Germany, that exhibit increased growth after disturbance. In particular, we focus on the following questions: (1) How reliably does PhytoCalc estimate dry weight, as well as nitrogen, phosphorus and potassium pools in the five species on clearcuts when compared to closed canopy conditions? (2) Can model predictions be improved by using the LDMC ratio as a correction factor under clearcut conditions? (3) Can specific correction factors for morphological plant groups be found?

\section{Materials and methods}

\section{Study site}

This study is part of a long-term forest conversion experiment (see Heinrichs and Schmidt 2009) and was carried out on four 1-ha clearcuts and in adjacent Norway spruce forest stands in the Solling hills, a low mountain range (up to $528 \mathrm{~m}$ above sea level) in the north-western part of Central Germany. Two clearcuts each were located at the study sites Otterbach (300 m a.s.l., mean annual precipitation $900 \mathrm{~mm}$, mean annual temperature of $7.7^{\circ} \mathrm{C}$ ) and Neuhaus $\left(509 \mathrm{~m}, 1,050 \mathrm{~mm}, 6.5^{\circ} \mathrm{C}\right.$; Gauer and Aldinger 2005). The Solling is formed of Triassic sandstone covered with loess. Predominant are podzolic brown soils (Dystric Cambisols) with a low base saturation and a good water supply. $\mathrm{C} / \mathrm{N}$ ratios are ca. 20 and the predominant humus form is humimor (Ellenberg et al. 1986; Scheffer and Schachtschabel 2002; Table 1). Amelioration liming containing magnesium was applied to both study sites in 1990, at Neuhaus also in 2001.

The clearcutting was conducted in the autumn of 2003. Four years after clearcutting, the plots received ca. $90 \%$ of the photosynthetic active radiation (PAR) above the herb layer, and were, among other species, covered by $R$. idaeus, E. angustifolium, D. flexuosa and A. capillaris (Heinrichs 
Table 1 Mean soil parameters $( \pm \mathrm{SE} ; 0-10 \mathrm{~cm}$ mineral soil) and the relative photosynthetic active radiation (PAR) measured above the herb layer on clearcuts and in surrounding closed forests at the study sites Neuhaus and Otterbach in the Solling hills

\begin{tabular}{lllllll}
\hline & $\mathrm{pH}$ & $\mathrm{C} / \mathrm{N}$ ratio & $\mathrm{N}\left(\mathrm{mg} \mathrm{g}^{-1}\right)$ & $\mathrm{P}\left(\mathrm{mg} \mathrm{g}^{-1}\right)$ & $\mathrm{K}\left(\mathrm{mg} \mathrm{g}^{-1}\right)$ & $\mathrm{PAR}(\%)$ \\
\hline $\begin{array}{l}\text { Neuhaus } \\
\text { Clearcut }\end{array}$ & $3.48( \pm 0.09)$ & $19.16( \pm 1.05)$ & $2.56( \pm 0.38)$ & $0.60( \pm 0.04)$ & $0.06( \pm 0.01)$ & $95.20( \pm 2.70)$ \\
$\quad$ Closed forest & $3.37( \pm 0.08)$ & $19.80( \pm 0.77)$ & $2.87( \pm 0.31)$ & $0.62( \pm 0.04)$ & $0.06( \pm 0.00)$ & $11.10( \pm 1.98)$ \\
$\begin{array}{l}\text { Otterbach } \\
\text { Clearcut }\end{array}$ & $3.51( \pm 0.07)$ & $20.18( \pm 1.05)$ & $1.86( \pm 0.36)$ & $0.37( \pm 0.04)$ & $0.06( \pm 0.01)$ & $88.92( \pm 3.62)$ \\
Closed forest & $3.21( \pm 0.05)$ & $20.33( \pm 0.50)$ & $2.10( \pm 0.29)$ & $0.38( \pm 0.02)$ & $0.10( \pm 0.02)$ & $12.86( \pm 3.34)$ \\
\hline
\end{tabular}

On each clearcut and forest plot soil values were obtained on four subplots à $100 \mathrm{~m}^{2}$, PAR (in \% of open field conditions) was measured on 20 subplots with LI-190 Quantum Sensors (Licor, Nebraska, USA) on overcast days with diffuse light conditions from July to September 2007; for each study site, two clearcuts and four forest plots were available

and Schmidt 2009; Table 1). The adjacent, around 100year-old, Norway spruce plantations (Galio harcyniciCulto-Piceetum; Zerbe 1993) with a PAR of around 10\% had an understorey dominated by Dryopteris dilatata, Oxalis acetosella and Vaccinium myrtillus, but A. capillaris and D. flexuosa were also frequent (Table 1).

Vegetation measurements, biomass harvest and nutrient analyses

Data for $D$. purpurea and $R$. idaeus were obtained from Klinck and Fröhlich (2009), a study conducted in the same study area. Data for A. capillaris, D. flexuosa and E. angustifolium were sampled as follows: On the clearcuts, $20 \times 0.25-\mathrm{m}^{2}$ plots were chosen for the harvest of A. capillaris and D. flexuosa. For E. angustifolium, which had higher shoot lengths than the grasses, $20 \times 1-\mathrm{m}^{2}$ plots were chosen for harvesting (Donita 1972). Plots were selected in order to achieve a wide range of cover values for each species, ranging from below $10 \%$ to more than $95 \%$. In addition, for both grass species, $20 \times 0.25-\mathrm{m}^{2}$ plots were chosen under closed canopy conditions. On each plot, the species mean shoot length was derived from the measurement of the elongated shoot length of 20 randomly chosen individuals. Extremely large or small individuals that did not represent the majority of plants on the plots were omitted, when more than 20 individuals were available, to avoid outlier effects. As D. purpurea was present mostly in flowering stems on all plots, mean shoot length measured on taller flowering individuals was used, to avoid underestimation (Klinck and Fröhlich 2009). Species cover was measured by applying image processing software (Adobe Photoshop CS3 10.0, Adobe Systems Inc.) to perpendicular photographs. The number of screen pixels occupied by a plant species was counted using the magic wand tool and related to the reference area marked by the wooden frame included in each image (Dietz and Steinlein 1996).
From 28 June 2007 to 8 August 2007, the aboveground biomass was harvested close to the soil surface, oven dried for at least $48 \mathrm{~h}$ at $60^{\circ} \mathrm{C}$, and weighed. For nutrient analyses, an aliquot of the dried material was finely milled and analysed for total nitrogen ( $\mathrm{N}$, combustion in Carlo Erba Elemental Analyser), potassium (K, atomic absorption spectrometer) and phosphorus ( $\mathrm{P}$, colorimeter, Schlichting et al. 1995), the latter elements extracted by pressure digestion in $65 \%$ nitric acid. Due to the different liming regimes at both study sites, calcium and magnesium were not regarded in this study.

\section{Estimation of LDMC}

Leaf dry matter content (LDMC) was measured following the procedure proposed by Wilson et al. (1999): We calculated the ratio of dry weight divided by saturated wet weight (fresh plant material) on leaf samples from five individuals per species and stand type. In total, 15 species were regarded including the five harvested ones, whereby the leaf material was collected independently of biomass harvests. The investigated species were assigned to the following morphological growth groups: Small herbs (Galium saxatile, Maianthemum bifolium, Trientalis europaea), tall herbs (D. purpurea, E. angustifolium), grasses (A. capillaris, Calamagrostis epigejos, D. flexuosa, Holcus mollis), sedges and rushes (Carex pilulifera, Juncus effusus, Luzula luzuloides), small shrubs/dwarf shrubs (Rubus fruticosus, $R$. idaeus, V. myrtillus). In general, five leaves per individual were collected (except M. bifolium). For the small statured $G$. saxatile, with thin and small leaves, the whole aboveground plant material was considered.

For each species, the ratio of LDMC under clearcut to LDMC under forest condition was calculated. Out of these species-specific ratios, a mean ratio per growth group was calculated. 
Biomass and nutrient pool estimation with PhytoCalc

The current calibration of the PhytoCalc model is based on biomass harvests of 46 forest species of Germany's northeastern lowlands and low mountain ranges. As shown in formula (1), the aboveground dry weight ( $\mathrm{DW}_{\text {predicted }}$ ) of a species is modelled as a function of percentage cover (C) and mean shoot length (SL):

$\mathrm{DW}_{\text {predicted }}=a C^{b} \mathrm{SL}^{c}$

Based on 1,700 data records of 46 species, Bolte (2006) fitted regression coefficients $a, b$ and $c$ for 13 different morphological growth groups. Iteratively, the combination of coefficients was determined representing the least residual sum of squares and the highest nonlinear coefficient of determination $\left(R^{2}\right.$; Table A1; Supplementary material).

Based on measured element concentrations, the 46 species were assigned to 11 element groups with similar nutrient concentrations in aboveground organs (Bolte et al. 2002). For each element group, average nutrient concentrations were determined $\left(\mathrm{NC}_{\mathrm{EG}}\right)$, which are the basis for nutrient pool estimations (Table A2; Supplementary material). Multiplying these average values by predicted dry weight determined for the constituent species (2) yields an estimate of the standing nutrient pool $\left(\mathrm{NP}_{\text {predicted }}\right)$ :
$\mathrm{NP}_{\text {predicted }}=\mathrm{DW}_{\text {predicted }} \mathrm{NC}_{\mathrm{EG}} 10^{-3}$

To compute dry weights and nutrient pools in this study, we applied the parameters for the growth groups small grasses (D. flexuosa), middle grasses (A. capillaris), tall herbs (D. purpurea, E. angustifolium) and small shrubs $(R$. idaeus), and for the element groups nutrient-poor grasses (A. capillaris, D. flexuosa), nutrient-poor herbs (D. purpurea, E. angustifolium) and Rubus-shrubs (R. idaeus).

PhytoCalc under clearcut situations

We computed separate regressions of the dependent variable aboveground dry weight of $A$. capillaris and $D$. flexuosa against the independent variables cover and mean shoot length in closed Norway spruce forests and on clearcuts, respectively. The influence of shoot length on biomass is adequately modelled by one power function across forests and clearcuts, whereas regressions of species cover against dry weights resulted in quite similar powers (but see D. flexuosa) across stand types but in higher slopes under clearcut conditions (Fig. 1). This implies a poor performance of PhytoCalc with parameters calibrated in forests under clearcut conditions. Thus, the performance was tested by contrasting observed and predicted dry weights.

Above-mentioned regressions suggest that the linear integration of one factor, which can account for the steeper
Fig. 1 Bivariate regressions of observed aboveground dry weight against cover and mean shoot length of $A$. capillaris and D. flexuosa, sampled on plots in closed Norway spruce forests (open circle) and on clearcuts (filled circle)
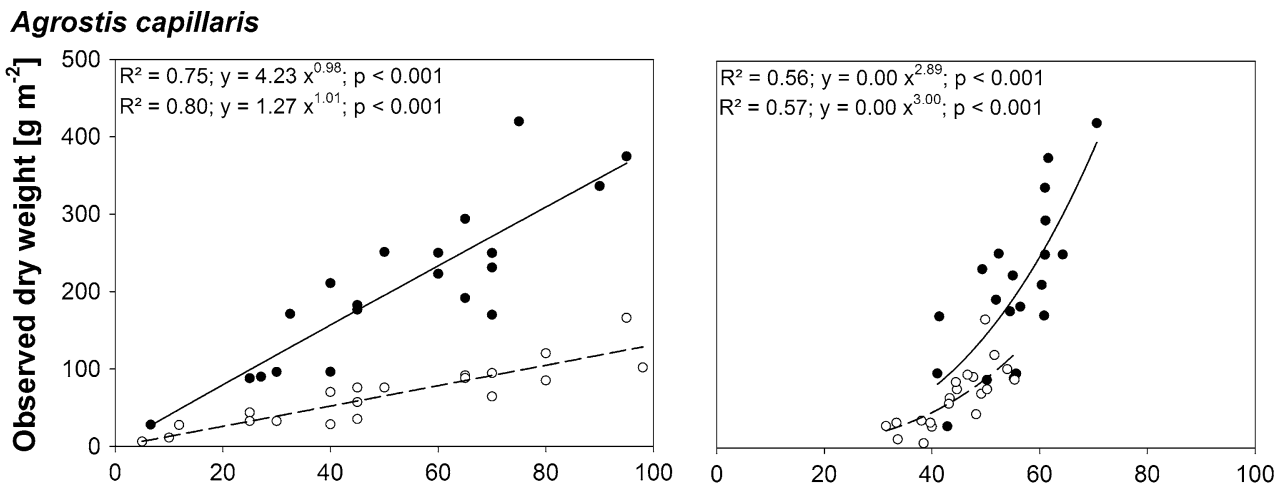

Deschampsia flexuosa
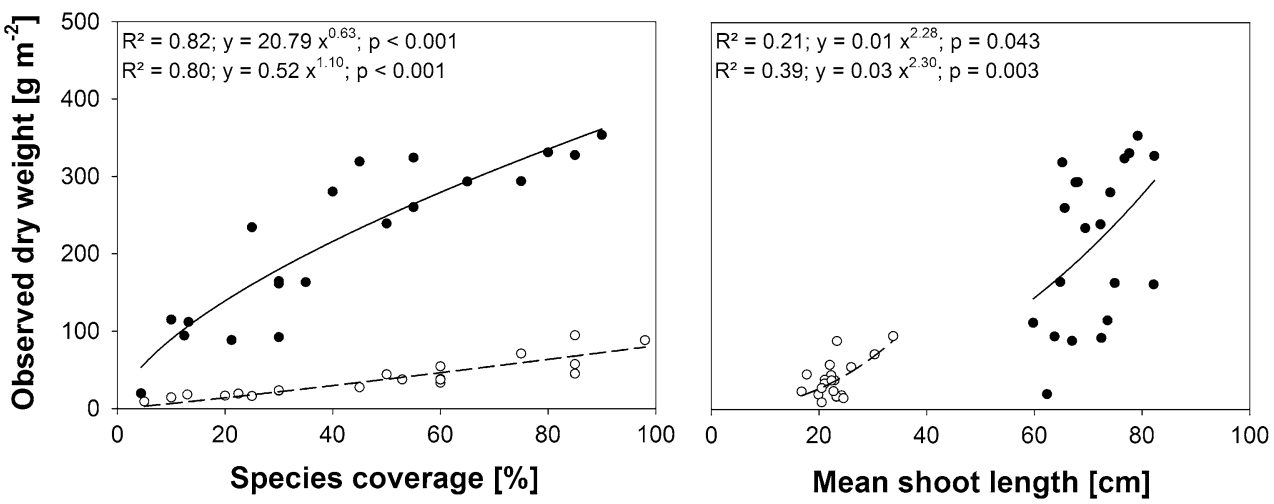
relationship between cover and biomass on clearcuts, into PhytoCalc might be sufficient in order to achieve reliable dry weight estimations. Such step could make a refitting of allometric functions used by PhytoCalc unnecessary. Thus, the calculated LDMC ratios between clearcut and forest conditions were established as correction factors (CF) for the five species investigated exemplarily.

To optimise the integration of $\mathrm{CF}$ in PhytoCalc, we multiplicatively linked the CF to Eq. (1) and performed a non-linear regression, which determined the $\beta$ value that resulted in the least residual sum of squares. A regression coefficient of $\beta=1$ would offer a simple multiplication of $\mathrm{DW}_{\text {predicted }}$ with $\mathrm{CF}$ as shown in formula (3). A $\beta \neq 1$ would point to the need for further adaptations of formula (3) to achieve reliable dry weight predictions.

$\mathrm{DW}_{\text {observed }}=a C^{b} \mathrm{SL}^{c}=\mathrm{DW}_{\text {predicted }} \mathrm{CF}^{\beta}$

According to formula (2), reliable nutrient pool estimations depend, beside reliable dry weight estimations, also on adequate element group concentrations used by PhytoCalc, which should reflect observed nutrient concentrations in the field. Thus, we compared nutrient concentrations observed in closed forests and on clearcuts with nutrient concentrations of the element groups using a one-sample $t$-test. In addition, to analyse whether the integration of the $\mathrm{CF}$ into nutrient pool estimations would improve estimation results, a non-linear regression using $\mathrm{CF}$ as covariable was calculated between observed and predicted nutrient pools $\left(\mathrm{NP}_{\text {observed }}=\mathrm{NP}_{\text {predicted }} \mathrm{CF}^{\beta}=\mathrm{DW}_{\text {predicted }}\right.$ $\left.\mathrm{NC}_{\text {EGpredicted }} 10^{-3} \mathrm{CF}^{\beta}\right)$. A regression coefficient of $\beta=0$ would make a correction of the used nutrient concentration unnecessary. A $\beta \neq 0$ would indicate a further correction of the used nutrient concentrations for the different element groups in PhytoCalc.

All observed values and their corresponding predicted values were compared calculating $R^{2}$ out of the variation around unity, which marks total identity of observed and predicted values.

Differences between group-specific CFs were analysed by the Kruskal-Wallis test. As the sample size for the growth groups was too small no post hoc test was performed.

All statistical analyses were conducted using R 2.8.1 (R Development Core Team 2008). Results were assumed to be significant at $P<0.05$.

\section{Results}

Influence of the study site

Among the studied species only E. angustifolium had been harvested at both study sites. The fact that there were no significant differences in nutrient concentrations between the sites $(\mathrm{N}: t=-0.84, P=0.41 ; \mathrm{P}: t=1.97 ; P=0.07$; $\mathrm{K}: t=2.09, P=0.06)$ indicates that pooling nutrient measurements was justified.

Performance of PhytoCalc on clearcuts: dry weight

PhytoCalc had been calibrated under closed canopy conditions; consequently, the usage of the growth group-specific functions resulted in close fits between predicted and observed dry weights (middle grass: A. capillaris, $R^{2}=0.79$; small grass: $D$. flexuosa. $R^{2}=0.89$ ). The maximum measured dry weights were $94.4 \mathrm{~g} \mathrm{~m}^{-2}$ for $D$. flexuosa and $165.8 \mathrm{~g} \mathrm{~m}^{-2}$ for A. capillaris compared to a maximum estimated value of $78.6 \mathrm{~g} \mathrm{~m}^{-2}$ and $139.0 \mathrm{~g} \mathrm{~m}^{-2}$.

In contrast to this, the steeper allometric relations between dry weight and the cover value on clearcuts produced large underestimations of the dry weight when using the same functions for both species (Table A1; Fig. A1; Supplementary material).

For both grass species, as well as for D. purpurea, $E$. angustifolium and $R$. idaeus, the LDMC differed significantly between closed canopy and clearcut conditions (Table 2). The ratio between both LDMC values was therefore derived to function as a correction factor for PhytoCalc predictions on clearcuts. The CF was lowest for

Table 2 Mean $\mathrm{LDMC}_{\text {clearcut }}$ and mean $\mathrm{LDMC}_{\text {forest }}$ based on five individuals per species and stand type, results of the Student's $t$-test comparing both values, and the calculated correction factor (CF)

\begin{tabular}{|c|c|c|c|c|c|}
\hline & $\mathrm{LDMC}_{\text {clearcut }}$ & $\mathrm{LDMC}_{\text {forest }}$ & $t$ & $\begin{array}{l}P \\
\text { value }\end{array}$ & $\mathrm{CF}$ \\
\hline Agrostis capillaris & 0.37 & 0.23 & 10.67 & $<0.001$ & 1.61 \\
\hline $\begin{array}{l}\text { Deschampsia } \\
\text { flexuosa }\end{array}$ & 0.37 & 0.24 & 10.39 & $<0.001$ & 1.54 \\
\hline Digitalis purpurea & 0.29 & 0.17 & 6.77 & $<0.001$ & 1.71 \\
\hline $\begin{array}{l}\text { Epilobium } \\
\text { angustifolium }\end{array}$ & 0.35 & 0.15 & 20.42 & $<0.001$ & 2.33 \\
\hline Rubus idaeus & 0.46 & 0.34 & 7.10 & $<0.001$ & 1.35 \\
\hline
\end{tabular}

$\mathrm{CF}$ was calculated as the ratio of $\mathrm{LDMC}_{\text {clearcut }}$ to $\mathrm{LDMC}_{\text {forest }}$

Table 3 Estimated $\beta$ coefficients, their standard error (SE) and $P$ value from non-linear regressions of observed against predicted dry weights on clearcuts using the CF as a covariable based on 20 studied plots per species

\begin{tabular}{llll}
\hline & $\beta$ & SE & $P$ value \\
\hline Agrostis capillaris & 1.96 & 0.08 & $<0.001$ \\
Deschampsia flexuosa & 2.48 & 0.18 & $<0.001$ \\
Digitalis purpurea & 2.42 & 0.11 & $<0.001$ \\
Epilobium angustifolium & 1.78 & 0.07 & $<0.001$ \\
Rubus idaeus & 2.40 & 0.18 & $<0.001$ \\
\hline
\end{tabular}


Table 4 Coefficients of determination resulting from contrasting observed dry weights with either uncorrected predicted values obtained from PhytoCalc or with predicted values corrected by multiplication with $\mathrm{CF}^{2}$

\begin{tabular}{|c|c|c|c|}
\hline & \multirow{2}{*}{$\begin{array}{l}\text { Morphological } \\
\text { group }\end{array}$} & \multicolumn{2}{|c|}{ Predicted dry weight } \\
\hline & & Uncorrected & $\begin{array}{l}\text { Corrected } \\
\text { with } \mathrm{CF}^{2}\end{array}$ \\
\hline Agrostis capillaris & Middle grass & 0.00 & $0.88 * * *$ \\
\hline Deschampsia flexuosa & Small grass & 0.00 & $0.93 * * *$ \\
\hline Digitalis purpurea & Tall herb & 0.00 & $0.63 * * *$ \\
\hline Epilobium angustifolium & Tall herb & 0.00 & $0.76 * * *$ \\
\hline Rubus idaeus & Small shrub & $0.35 * *$ & $0.89 * * *$ \\
\hline
\end{tabular}

The morphological group to which each species is assigned to indicates the applied regression function according to Table A1 (Supplementary material)

*** $P \leq 0.001 ; * * P \leq 0.01, n=20$ plots per species

the small shrub $R$. idaeus and highest for D. purpurea and E. angustifolium. The two grass species showed intermediate values.

Regression analyses of observed against predicted dry weights using the $\mathrm{CF}$ as covariable resulted in coefficients $\beta$ differing all significantly from 0 , and ranging from 1.78 for E. angustifolium to 2.48 for D. flexuosa (Table 3). This indicated to include the CFs in its quadratic term into PhytoCalc by a simple multiplication when used on clearcuts. Such CF integration resulted in significant determination coefficients of 0.63 for $D$. purpurea to 0.89 for $R$. idaeus when contrasting observed and predicted dry weight values and brought the regression slope of each species close to unity, whereas the usage of uncorrected values did not allow the calculation of determination coefficients around unity in most cases (Table 4; Fig. 2a vs. b).

Considering all species together, a comparison between predicted dry weights corrected using $\mathrm{CF}^{2}$ and observed dry weights resulted in a significant $R^{2}$ of 0.77 . The linear regression equation of this comparison forced through the origin was $\mathrm{DW}_{\text {observed }}=0.995 \mathrm{DW}_{\text {predicted }}$ with a residual standard error of 0.027 . The slope was not significantly different from unity $(t=-0.180, P=0.857)$.

Performance of PhytoCalc on clearcuts: nutrient pools

Beside adequately predicted dry weights, reliable nutrient concentrations of element groups used within PhytoCalc are necessary for nutrient pool predictions. $\mathrm{N}$ concentrations of A. capillaris and D. flexuosa observed under closed canopy were higher than the according element group concentration. For D. flexuosa, this was also the case for K (Fig. 3). However, determination coefficients, when contrasting observed nutrient pools and predicted nutrient pools, were all significant and ranged from 0.66 for the nitrogen pool of A. capillaris to 0.82 for the phosphorus pool of D. flexuosa (Table 5). On clearcuts, though, nutrient concentrations of harvested plants were significantly lower for all species (except for the K- and P-concentrations of Rubus idaeus) than PhytoCalc concentrations (Fig. 3). Consequently, when contrasting observations and
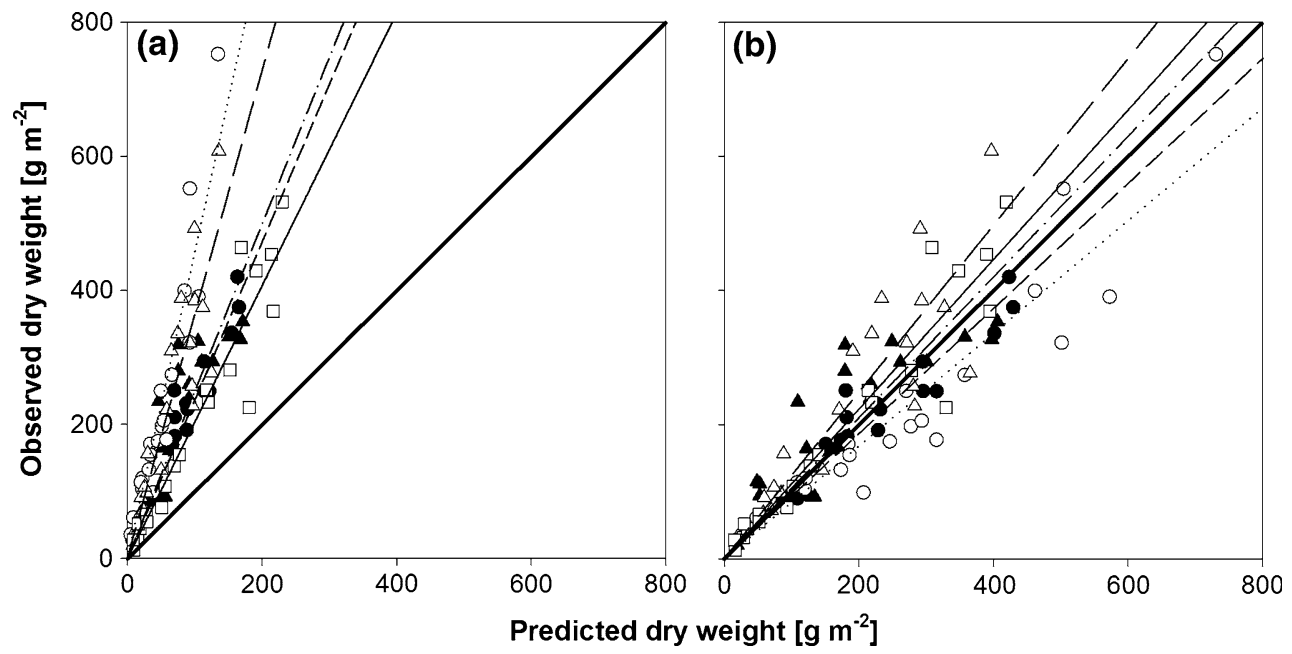

Fig. 2 Modelled vs. observed dry weights on clearcuts for (filled circle) A. capillaris, (filled triangle) D. flexuosa, (open triangle) D. purpurea, (open circle) E. angustifolium and (open square) R. idaeus; a using the uncorrected PhytoCalc model, $\mathbf{b}$ using the model corrected by multiplication with $\mathrm{CF}^{2}$; Regression lines are given for each species (A. capillaris: short dash; D. flexuosa: dash dot; D. purpurea: long dash; E. angustifolium: dotted; $R$. idaeus: solid line). The thick solid line represents unity; the degree of tilting from unity in $\mathbf{a}$ is proportional to LDMC ratios (A. capillaris: $1.61 ; D$. flexuosa: $1.54 ; D$. purpurea: $1.71 ;$ E. angustifolium: $2.33 ; R$. idaeus: 1.35$) ; R^{2}$ values out of the variation around unity are given in Table 4 

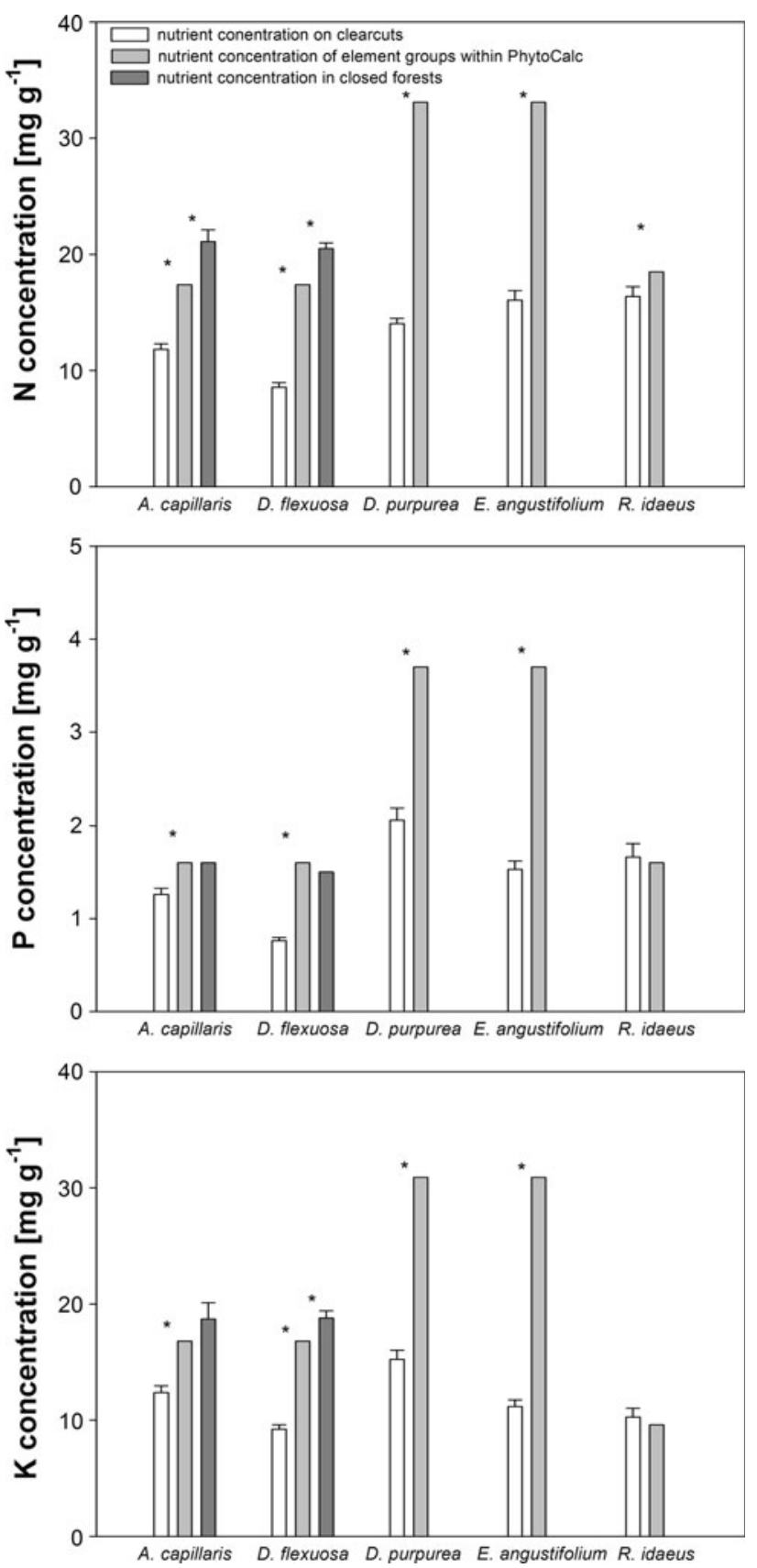

Fig. 3 Observed nutrient concentrations in closed Norway spruce stands for A. capillaris and D. flexuosa and on clearcuts for both grasses, D. purpurea, E. angustifolium and $R$. idaeus in comparison with element group concentrations applied by PhytoCalc for these species; * indicates significant differences between observed nutrient concentration determined on 20 plots and element group concentration based on one-sample $t$-test; observe the different vertical axis scale for the $\mathrm{P}$ concentration

predictions, determination coefficients were low in most cases (Table 5). A regression analysis of observed against predicted nutrient pools using the $\mathrm{CF}$ as covariable resulted in $\beta$ coefficients significantly different from 0 for $A$. capillaris, D. flexuosa, D. purpurea, and E. angustifolium (Table 6). The results indicate to correct the nutrient concentration implemented within PhytoCalc by multiplication with $\mathrm{CF}^{-1}$. This correction resulted in higher determination coefficients for all species (except $R$. idaeus) than the usage of uncorrected concentrations (Table 5). The determination coefficients ranged from 0.65 to 0.88 for $\mathrm{N}, 0.48-0.80$ for $\mathrm{K}$, and $0.58-0.77$ for P. D. flexuosa, however, showed lower values.

Morphological group-specific correction factors

The tall herbs, D. purpurea and E. angustifolium, disclosed in general larger differences between observed nutrient concentrations and element group concentrations than the other species (Fig. 3). This is in accordance with the highest CF found for the growth group of tall herbs. Small herbs, as well as sedges and rushes showed the smallest values, whilst the group of small and dwarf shrubs depicted an intermediate value (Table 7). The importance of growth group-specific CFs was verified by the Kruskal-Wallis test $\left(\chi^{2}=10.38, d f=4, P\right.$ value $\left.=0.034\right)$, which showed a significant difference between growth groups despite the small sample size.

\section{Discussion}

PhytoCalc performance under closed canopy conditions

In closed Norway spruce forests of the Solling the model PhytoCalc estimated reliable aboveground dry weights for A. capillaris and D. flexuosa, consistent with results of Höhne (1962), Höhne et al. (1981) and Bolte (1999) in temperate coniferous and deciduous forests. A good fit was also found when contrasting observed and predicted N-, Pand K-pools, although observed $\mathrm{N}$ and $\mathrm{K}$ concentrations were higher than concentrations applied by PhytoCalc. A. capillaris and D. flexuosa are typical species of infertile sites with low nitrogen concentrations $(1-2 \% \mathrm{~N})$ compared to other grasses colonising more nutrient rich sites (e.g. Brachypodium sylvaticum, Melica uniflora: $2.5-3.3 \% \mathrm{~N}$ ) or compared to herbs having in general higher nutrient concentrations (Höhne 1962). In the Solling, though, the soils show a better nitrogen supply than soils in Germany's north-east, where the main part of datasets used for the PhytoCalc calibration was sampled. This is to some extent caused by higher nitrogen depositions in the Solling compared to north-east Germany (Gauger et al. 2001). Nevertheless, the measured concentrations are in accordance with other studies (Höhne 1962, 1963; Bennert 1980; Chapin 1980; Höhne et al. 1981). In general, nutrient concentrations of species are species traits (however, traits with a 
Table 5 Coefficients of determination of the comparisons of observed against predicted nutrient pools under closed forests and on clearcuts for each species

\begin{tabular}{|c|c|c|c|c|c|c|c|}
\hline \multirow{2}{*}{$\begin{array}{l}\text { Nutrient concentration } \\
\text { within PhytoCalc }\end{array}$} & \multirow[t]{2}{*}{ Element group } & \multicolumn{3}{|c|}{ Closed forest } & \multicolumn{3}{|l|}{ Clearcut } \\
\hline & & $\mathrm{N}$ & $\mathrm{P}$ & $\mathrm{K}$ & $\mathrm{N}$ & $\mathrm{P}$ & $\mathrm{K}$ \\
\hline Agrostis capillaris & Nutrient-poor grass & & & & & & \\
\hline Uncorrected & & $0.66 * * *$ & $0.81 * * *$ & $0.72 * * *$ & 0.00 & $0.62 * * *$ & $0.37 * *$ \\
\hline Corrected & & ND & ND & ND & $0.88 * * *$ & $0.67 * * *$ & $0.76 * * *$ \\
\hline Deschampsia flexиоsa & Nutrient-poor grass & & & & & & \\
\hline Uncorrected & & $0.75 * * *$ & $0.82 * * *$ & $0.79 * * *$ & 0.00 & 0.00 & 0.00 \\
\hline Corrected & & ND & ND & ND & $0.31 *$ & 0.00 & $0.44 * *$ \\
\hline Epilobium angustifolium & Nutrient-poor herb & & & & & & \\
\hline Uncorrected & & ND & ND & ND & 0.00 & 0.00 & 0.00 \\
\hline Corrected & & ND & ND & ND & $0.75 * * *$ & $0.77 * * *$ & $0.48 * *$ \\
\hline Digitalis purpurea & Nutrient-poor herb & & & & & & \\
\hline Uncorrected & & ND & ND & ND & 0.00 & 0.17 & 0.00 \\
\hline Corrected & & ND & ND & ND & $0.65 * * *$ & $0.58 * * *$ & $0.70 * * *$ \\
\hline Rubus idaeus & Rubus shrub & & & & & & \\
\hline Uncorrected & & ND & ND & ND & $0.84 * * *$ & $0.84 * * *$ & $0.96 * * *$ \\
\hline Corrected & & ND & ND & ND & $0.80 * * *$ & $0.64 * * *$ & $0.91 * * *$ \\
\hline
\end{tabular}

For the prediction on clearcuts, either the uncorrected nutrient concentrations implemented within PhytoCalc or the same nutrient concentrations corrected by multiplication with $\mathrm{CF}^{-1}$ were used. The assignment of the species to the element group indicates, which concentrations were used for prediction according to Table A2 (Supplementary material)

*** $P \leq 0.001$; ** $P \leq 0.01$; $P \leq 0.05, N D$ not defined, $n=20$ plots per species

Table 6 Estimated $\beta$ coefficients, their standard error (SE) and $P$ value from non-linear regressions of observed against predicted nutrient pools using the $\mathrm{CF}$ as a covariable, $\mathrm{n}=20$ plots per species

\begin{tabular}{|c|c|c|c|c|c|c|c|c|c|}
\hline & \multicolumn{3}{|l|}{$\mathrm{N}$} & \multicolumn{3}{|l|}{$P$} & \multicolumn{3}{|l|}{$\mathrm{K}$} \\
\hline & $\beta$ & SE & $P$ & $\beta$ & SE & $P$ & $\beta$ & SE & $P$ \\
\hline Agrostis capillaris & -0.880 & 0.085 & $<0.001$ & -0.593 & 0.118 & $<0.001$ & -0.727 & 0.122 & $<0.001$ \\
\hline Deschampsia flexuosa & -1.205 & 0.179 & $<0.001$ & -1.275 & 0.204 & $<0.001$ & -0.940 & 0.191 & $<0.001$ \\
\hline Digitalis purpurea & -1.194 & 0.130 & $<0.001$ & -0.735 & 0.142 & $<0.001$ & -0.946 & 0.131 & $<0.001$ \\
\hline Epilobium angustifolium & -1.099 & 0.086 & $<0.001$ & -1.298 & 0.077 & $<0.001$ & -1.449 & 0.068 & $<0.001$ \\
\hline Rubus idaeus & -0.084 & 0.209 & 0.693 & 0.339 & 0.245 & 0.183 & -0.188 & 0.236 & 0.436 \\
\hline
\end{tabular}

relative high plasticity), leading to higher differences in nutrient storage between different species or species groups than between sites (Höhne 1962; Thompson et al. 1997).

Performance of PhytoCalc on clearcuts: dry weight

Although PhytoCalc worked well under a closed Norway spruce canopy, it gave inadequate results on small-scale clearcuts for all analysed species as already shown by Klinck and Fröhlich (2009). The application of a simple linear transformation by using the presented LDMC ratio as a correction factor resulted in predicted dry weights of A. capillaris, D. flexuosa, D. purpurea, E. angustifolium and $R$. idaeus that explained $62-93 \%$ of the variance of observations. These predictions were consistent with biomass values found by different authors under high light availability for these species (van Andel 1975; Al-Mufti et al. 1977; van Baalen and Prins 1983; Fahey et al. 1991). Differences in biomass or growth performance under different light regimes have been reported before for D. Alexuosa (Scurfield 1954), D. purpurea (van Baalen and Prins 1983), E. angustifolium (Myerscough 1980) and R. idaeus (Ricard and Messier 1996), with all species showing maximum dry weights on open sites. This can be explained by a change in the leaf anatomy, as shown for the plasticity of LDMC: plants growing under high irradiance generally have a dense vascular system and a dense, often multilayered, mesophyll, leading to higher leaf dry weights compared to plants of the same species growing in shady conditions (Larcher 2001; Ricard and Messier 1996; Myerscough 1980). Meziane and Shipley (1999) and Shipley (2000) also showed that leaf traits of several 
Table 7 Leaf dry matter content of understorey species on clearcuts and in closed forests assigned to different morphological groups and the calculated species-specific and morphological group-specific correction factors, LDMC values are based on five individuals per species

\begin{tabular}{|c|c|c|c|}
\hline & Clearcut & Forest & $\mathrm{CF}$ \\
\hline \multicolumn{4}{|l|}{ Small herbs } \\
\hline Galium saxatile & 0.25 & 0.22 & 1.14 \\
\hline Maianthemum bifolium & 0.28 & 0.24 & 1.17 \\
\hline Trientalis europea & 0.34 & 0.24 & 1.42 \\
\hline Growth group & & & 1.24 \\
\hline \multicolumn{4}{|l|}{ Tall herbs } \\
\hline Digitalis purpurea & 0.29 & 0.17 & 1.71 \\
\hline Epilobium angustifolium & 0.35 & 0.15 & 2.33 \\
\hline Growth group & & & 2.02 \\
\hline \multicolumn{4}{|l|}{ Poaceae } \\
\hline Calamagrostis epigejos & 0.47 & 0.34 & 1.38 \\
\hline Holcus mollis & 0.42 & 0.23 & 1.83 \\
\hline Agrostis capillaris & 0.37 & 0.23 & 1.61 \\
\hline Deschampsia flexиosa & 0.37 & 0.24 & 1.54 \\
\hline Growth group & & & 1.59 \\
\hline \multicolumn{4}{|l|}{ Cyperaceae/Juncaceae } \\
\hline Carex pilulifera & 0.45 & 0.39 & 1.15 \\
\hline Juncus effusus & 0.41 & 0.32 & 1.28 \\
\hline Luzula luzuloides & 0.40 & 0.34 & 1.18 \\
\hline Growth group & & & 1.20 \\
\hline \multicolumn{4}{|l|}{ Small shrubs/dwarf shrubs } \\
\hline Rubus fruticosus & 0.44 & 0.35 & 1.26 \\
\hline Rubus idaeus & 0.46 & 0.34 & 1.35 \\
\hline Vaccinium myrtillus & 0.46 & 0.35 & 1.31 \\
\hline Growth group & & & 1.31 \\
\hline
\end{tabular}

species change uniformly with irradiance: lamina and mesophyll thicknesses increased with light availability, whereas the leaf water content decreased. Garnier and Laurent (1994) presented a negative correlation of the leaf water content with the cross-sectional area occupied by vascular tissue and sclerenchyma, which increase with irradiance.

Other factors resulting in a larger dry weight under high irradiance can be a higher density of stems but with leaves covering a smaller area, a larger degree of overlaying vegetation components, or thicker stems, especially for species like $D$. purpurea. Compared to these factors, though, which can differ for each study plot or only account for distinct species groups, the LDMC can be easily recorded for a larger area by sampling leaves from 5 to 10 individuals (Cornelissen et al. 2003) under the different light regimes. The difference in this plant trait can then be a successful correction tool for differences in density and quality of the plant tissue and consequently, the aboveground dry weight with varying environmental conditions, as shown in this study.

PhytoCalc performance on clearcuts: nutrient pools

Nutrient concentrations on clearcuts were lower than average element group concentrations used by PhytoCalc. This is in accordance with differences detected by Fahey et al. (1991) for A. capillaris and D. flexuosa, and by Högbom and Högberg (1991) and Palviainen et al. (2005) for $D$. flexuosa comparing clearcuts and closed forests.

As already mentioned earlier, under open site conditions leaf structure may change: high light availability increases leaf sclerophylly, which is negatively correlated with nutrient concentrations (Loveless 1961; Garnier and Laurent 1994). Furthermore, on clearcuts, plants invest more into stems; the proportion of leaves on the dry weight decreases (Scurfield 1954; van Baalen and Prins 1983). Compared to other plant organs, though, leaves store the largest amount of nutrients (mainly N, P, Ca, Mg, S; Höhne 1962; van Andel and Jager 1981; Larcher 2001). Consequently, also the nutrient concentrations used by PhytoCalc had to be adjusted to clearcut conditions. Non-linear regressions showed that the inverse of the correction factor, proposed in this study, is suited to adjust the nutrient concentration. This factor accounted for the reduced nutrient concentration due to a larger degree of sclerenchymatic tissue within leaves under high irradiance compared to low light values. However, for some species, especially $D$. flexuosa, this correction is not sufficient as predictions explained no variance of observations for $\mathrm{P}$ and only 31 and $44 \%$ for $\mathrm{N}$ and $\mathrm{K}$, respectively. For this species the discrepancy regarding the existence of flowering stems between closed forest conditions and clearcuts is extremely severe (Scurfield 1954).

Besides the higher sclerophylly of leaves, other factors can as well account for lower nutrient concentrations and thus for the still unexplained variance of observed nutrient pools by corrected predictions: On clearcuts, stems can already show indications of lignification compared to forest conditions. $\mathrm{K}$ is preferentially stored in flowers and fruits, and not impoverished in stems; however, the leaching of this highly soluble element, due to higher amounts of rainfall reaching the plants on clearcuts, seems to be more important (Höhne 1962; Morton 1977; Larcher 2001). Furthermore, most of these species are growth-limited due to the low light availability under a closed canopy (Scurfield 1954; van Andel 1975; Al-Mufti et al. 1977; van Baalen and Prins 1983; Strengbom et al. 2004). Thus, under clearcut conditions growth is largely enhanced, although the amount of available nutrients might not increase at the same rate, despite a faster mineralisation after clearcutting. The consequence is a "dilution-effect" 
within the plant biomass (Larcher 2001) characterised by a negative correlation between the nutrient concentration and the aboveground biomass as found by Mellert et al. (1998) and Steiner et al. (1998). The fact that forest residues were removed on the Solling plots after clearcutting, avoiding further release of nutrients from decomposing branches (Stevens and Hornung 1990), contributes as well to the "dilution-effect". Within R. idaeus, though, nutrient concentrations showed almost no difference between observations on clearcuts and concentrations of the corresponding element group. Ricard and Messier (1996) found no relative increase in stem compared to leaf biomass with increasing light intensity. Furthermore, woody species in general show a slower growth rate. The dwarfshrub species $V$. myrtillus, for example, also showed constant nutrient concentrations when comparing clearcut and forest conditions (Altegrim and Sjöberg 1996; Palviainen et al. 2005). Thus, the plasticity of species under different environmental conditions seems to depend on specific morphological characteristics. Also CFs calculated for different morphological groups in this study were significantly different from each other. One explanation for the differences between these growth groups is generally that small plants grow in the shadow of taller plants; this is also true on clearcuts. Taller herbs, instead, are totally exposed to sun light. Grasses can dominate clearcuts and are therefore also found under full sunlight. Rushes and sedges have tougher leaves with a high sclerenchymatic content, even under forest conditions, explaining the smaller differences in LDMC between environmental conditions. The same is true for dwarf shrubs and small shrubs. Thus, it might be reasonable in the future to include one correction factor for each morphological growth group into PhytoCalc to apply this model to clearcut conditions. Thereby, some growth groups chosen in the present study differed from morphological growth groups used by Bolte (1999, 2006): we have considered all woody species together, but grasses and rushes/sedges were considered separately because of their differences in leaf physiology. However, the consideration of more species may lead to a finer differentiation than presently available.

\section{Conclusions}

PhytoCalc is an applicable model for estimating dry weight and nutrient pools of Central European forest communities. By integrating the variability of the easy determinable LDMC under different irradiance regimes as a linear correction factor, the model is also usable in open areas such as larger areas of windthrow or clearcuts. These are expected to occur more frequently in the future due to severe winter storms or during the conversion of Norway spruce stands into mixed stands. On open sites, LDMC accounts for a higher tissue density within species, as well as for lower nutrient concentrations compared to forest conditions, a consequence of the higher sclerophylly of leaves under high irradiance. Different morphological groups showed significantly different $\mathrm{CFs}$, which suggests to integrate one correction factor per morphological group into PhytoCalc to adjust for open site conditions. The group-specific ratios detected here are, however, only based on a few number of species that were frequent at the Solling sites. Thus, a further integration of species being more frequent in other forest types is necessary as well as the integration of other study sites and forest types to achieve a standard correction factor that is generally applicable on clearcuts. Nevertheless, particular attention should be paid to species known to be able to become dominant during secondary succession after clearcut or windthrow as they will account for most of the biomass then.

However, here, only the extremes (closed canopy vs. full light availability) have been analysed, and the results cannot be transferred to situations in highly thinned forest stands, in forest gaps, at forest edges or on clearcuts where regenerating trees expand rapidly. Therefore, the reaction of plants to different levels of irradiance should be analysed along a gradient from low to high light availability. Thus, threshold values of light availability can be identified which indicate the necessity of a correction of estimated values. In addition, a regression function could be used as a correction factor emanating from plant reactions dependent on light availability.

Acknowledgments We would like to thank Andrea Bauer, Martina Knaust, Andreas Parth, Heiko Rubbert and Theresa Waldmann for help with the field and laboratory work, Ruth Gilbert for language correction and Andreas Bolte, one anonymous reviewer and Christian Ammer as subject editor for helpful comments on the manuscript.

Open Access This article is distributed under the terms of the Creative Commons Attribution Noncommercial License which permits any noncommercial use, distribution, and reproduction in any medium, provided the original author(s) and source are credited.

\section{References}

Al-Mufti MM, Sydes CL, Furness SB, Grime JP, Band SR (1977) A quantitative analysis of shoot phenology and dominance in herbaceous vegetation. J Ecol 65:759-791

Altegrim O, Sjöberg K (1996) Response of bilberry to clear-cutting and single-tree selection harvests in uneven-aged boreal Picea abies forests. For Ecol Manage 86:39-50

Bartsch N (2000) Element release in beech (Fagus sylvatica L.) forest gaps. Water Air Soil Poll 122:3-16 
Bennert HW (1980) Über die stoffliche Zusammensetzung von Waldbodenpflanzen eines montanen Hainsimsen-Buchenwaldes I. Asche-, Stickstoff- und Proteingehalt. Flora 170:433-455

Blank JL, Olson RK, Vitousek PM (1980) Nutrient uptake by a diverse spring ephemeral community. Oecologia 47:96-98

BMELV (Bundesministerium für Ernährung, Landwirtschaft und Verbraucherschutz) (2006) Arbeitsanleitung zur zweiten bundesweiten Bodenzustandserhebung im Wald (BZE II). Bonn

Bolte A (1999) Abschätzung von Trockensubstanz-, Kohlenstoff- und Nährelementvorräten der Waldbodenflora - Verfahren, Anwendung und Schätztafeln. Forstwiss Beitr Tharandt 7, 129 pp

Bolte A (2006) Biomasse- und Elementvorräte der Bodenvegetation auf Flächen des forstlichen Umweltmonitorings in RheinlandPfalz (BZE, EU Level II). Ber Forschungszentr Waldökosyst, Reihe B, Bd. 72, 80 pp

Bolte A, Anders S, Roloff A (2002) Schätzmodelle zum oberirdischen Vorrat der Waldbodenflora an Trockensubstanz, Kohlenstoff und Makronährelementen. Allg Forst Jagdztg 173:57-66

Bolte A, Lambertz B, Steinmeyer A, Kallweit R, Meesenburg H (2004) Zur Funktion der Bodenvegetation im Nährstoffhaushalt von Wäldern - Studien auf Dauerbeobachtungsflächen des EU Level II-Programms in Norddeutschland. Forstarchiv 75:207220

Boring LR, Monk CD, Swank WT (1981) Early regeneration of a clear-cut southern Appalachian forest. Ecology 62:1244-1253

Chapin SF III (1980) The mineral nutrition of wild plants. Annu Rev Ecol Syst 11:233-260

Cornelissen JHC, Lavorel S, Garnier E, Díaz S, Buchmann N, Gurvich DE, Reich PB, ter Steege H, Morgan HD, van der Heijden MAG, Pausas JG, Poorter H (2003) A handbook of protocols for standardised and easy measurement of plant functional traits worldwide. Aust J Bot 51:335-380

De Vries W, Vel E, Reinds GJ, Deelstra H, Klap JM, Leeters EEJM, Hendriks CMA, Kerkvoorden M, Landmann G, Herkendell J, Haussmann T, Erisman JW (2003) Intensive monitoring of forest ecosystems in Europe 1. Objectives, set-up and evaluation strategy. For Ecol Manage 174:77-95

Dietz H, Steinlein T (1996) Determination of plant species cover by means of image analysis. J Veg Sci 7:131-136

Donita N (1972) Zahl und Größe der Probeflächen bei der direkten Bestimmung der Krautschicht-Biomasse im Walde. Oecol Plant 7:85-94

Ellenberg H, Mayer R, Schauermann J (1986) Ökosystemforschung Ergebnisse des Sollingprojekts. Ulmer, Stuttgart

Fahey TJ, Hill MO, Stevens PA, Hornung M, Rowland P (1991) Nutrient accumulation in vegetation following conventional and whole-tree harvest of Sitka spruce plantations in North Wales. Forestry 64:271-288

Garnier E, Laurent G (1994) Leaf anatomy, specific mass and water content in congeneric annual and perennial grass species. New Phytol 128:725-736

Gauer J, Aldinger E (2005) Waldökologische Naturräume Deutschlands - Forstliche Wuchsgebiete und Wuchsbezirke - mit Karte 1:1.000.000. Mitt Ver Forstl Standortskde Forstpflanzenz 43, $324 \mathrm{pp}$

Gauger T, Köble R, Spranger T, Bleeker A, Draaijers G (2001) Deposition loads of sulphur and nitrogen in Germany. Water Air Soil Poll: Focus 1:353-373

Gilliam FS (2007) The ecological significance of the herbaceous layer in temperate forest ecosystems. Bioscience 57:845-858

Heinrichs S, Schmidt W (2009) Short-term effects of selection and clear cutting on the shrub and herb layer vegetation during the conversion of even-aged Norway spruce stands into mixed stands. For Ecol Manage 258:667-678
Högbom L, Högberg P (1991) Nitrate nutrition of Deschampsia flexuosa (L.) Trin. in relation to nitrogen deposition in Sweden. Oecologia 87:488-494

Höhne H (1962) Vergleichende Untersuchungen über Mineralstoffund Stickstoffgehalt sowie Trockensubstanzproduktion von Waldbodenpflanzen. Arch Forstwes 11:1085-1141

Höhne H (1963) Der Mineralstoff- und Stickstoffgehalt von Waldbodenpflanzen in Abhängigkeit vom Standort. Arch Forstwes 12:791-805

Höhne H, Fiedler HJ, Ilgen G (1981) Untersuchungen über den Mineralstoffgehalt von Deschampsia flexuosa (L.) P.B. als Bestandteil von Fichtenforst-Ökosystemen. Flora 171:199-215

Kellomäki S (1974) Metsän aluskasvillisuuden biomassan ja peittävyyden välisestä suhteesta (On the relation between biomass and coverage in ground vegetation of forest stands). Silva Fenn 8:20-46

Klinck U, Fröhlich D (2009) Application of the phytomass and elemental stock model "PhytoCalc" under clear cut conditions. Allg Forst Jagdztg 180:15-21

Larcher W (2001) Ökophysiologie der Pflanzen. 6. Auflg, Ulmer, Stuttgart

Loveless AR (1961) A nutritional interpretation of sclerophylly based on differences in the chemical composition of sclerophyllous and mesophytic leaves. Ann Bot 25:168-184

Marks PL, Bormann FH (1972) Revegetation following forest cutting: mechanisms to return to steady state nutrient cycling. Science 176:914-915

Mellert K-H, Kölling C, Rehfuess KE (1998) Vegetationsentwicklung und Nitrataustrag auf 13 Sturmkahlflächen in Bayern. Forstarchiv 69:3-11

Meziane D, Shipley B (1999) Interacting determinants of specific leaf area in 22 herbaceous species: effects of irradiance and nutrient availability. Plant Cell Environ 22:447-459

Mölder A, Bernhardt-Römermann M, Schmidt W (2008) Herb-layer diversity in deciduous forests: Raised by tree richness or beaten by beech? For Ecol Manage 256:272-281

Morton AJ (1977) Mineral nutrient pathways in a Molinietum in autumn and winter. J Ecol 65:993-999

Mrotzek R (1998) Wuchsdynamik und Mineralstoffhaushalt der Krautschicht in einem Buchenwald auf Basalt. Ber Forschungszentr Waldökosyst, Reihe A, Bd. 152, 197 pp

Muller RN (2003) Nutrient relations of the herbaceous layer in deciduous forest ecosystems. In: Gilliam FS, Roberts MR (eds) The herbaceous layer in forests of eastern North America. Oxford University Press, New York, pp 15-37

Muukkonen P, Mäkipää R, Laiho R, Minkkinen K, Vasander H, Finér L (2006) Relationship between biomass and percentage cover in understorey vegetation of boreal coniferous forests. Silva Fenn 40:231-245

Myerscough PJ (1980) Epilobium angustifolium L. J Ecol 68:10471074

Outcalt KW, White EH (1981) Understory biomass and nutrients 2 years after timber harvest in northern Minnesota. Can J For Res 11:305-308

Palviainen M, Finér L, Mannerkoski H, Piirainen S, Starr M (2005) Responses of ground vegetation species to clear-cutting in a boreal forest: aboveground biomass and nutrient contents during the first 7 years. Ecol Res 20:652-660

R Development Core Team (2008) R: a language and environment for statistical computing. R Foundation for Statistical Computing, Vienna, Austria. http://www.R-project.org

Ricard J-P, Messier C (1996) Abundance, growth and allometry of red raspberry (Rubus idaeus L.) along a natural light gradient in a northern hardwood forest. For Ecol Manage 81:153-160 
Rodenkirchen H (1995) Nutrient pools and fluxes of the ground vegetation in coniferous forests due to fertilizing, liming and amelioration. Plant Soil 168-169:383-390

Röttgermann M, Steinlein T, Beyschlag W, Dietz H (2000) Linear relationships between aboveground biomass and plant cover in low open herbaceous vegetation. J Veg Sci 11:145-148

Scheffer F, Schachtschabel P (2002) Lehrbuch der Bodenkunde. 15. Auflg., Spektrum, Heidelberg

Schlichting E, Blume P, Stahr K (1995) Bodenkundliches Praktikum, 2. Auflg., Blackwell, Berlin

Schulze ED, Beck E, Müller-Hohenstein K (2002) Pflanzenökologie. Spektrum, Heidelberg

Schulze I-M, Bolte A, Seidling W, Stetzka K-M, Wellbrock N (2000) Vegetationskundliche Aufnahmen im Level II-Programm: Methoden, Auswertungen, erste Ergebnisse. Forstarchiv 71:76-83

Schulze I-M, Bolte A, Schmidt W, Eichhorn J (2009) Phytomass, litter and net primary production of herbaceous layer. In: Brumme R, Khanna P (eds) Functioning and management of European beech ecosystems. Ecol Stud, vol 208, pp 155-181

Scurfield G (1954) Deschampsia flexuosa (L.) Trin. J Ecol 42:225233

Seidling W (2005) Ground floor vegetation assessment within the intensive (Level II) monitoring of forest ecosystems in Germany: chances and challenges. Eur J Forest Res 124:301-312

Shipley B (2000) Plasticity in relative growth rate and its components following a change in irradiance. Plant Cell Environ 23:12071216

Siccama TG, Bormann FH, Likens GE (1970) The Hubbard Brook ecosystem study: productivity, nutrients, and phytosociology of the herbaceous layer. Ecol Monogr 40:389-402

Steiner A, Bolte A, Schneider BU, Hüttl RF (1998) Phytomasseund Nährelementvorräte unterschiedlich stickstoffbeeinflußter
Kiefernbestände (Pinus sylvestris L.) des nordostdeutschen Tieflandes. Verh Ges Ökol 28:421-428

Stevens PA, Hornung M (1990) Effect of harvest intensity and ground flora establishment on inorganic $\mathrm{N}$ leaching from Sitka spruce plantation in north Wales, UK. Biogeochemistry 10:53-65

Strengbom J, Näsholm T, Ericson L (2004) Light, not nitrogen, limits growth of the grass Deschampsia flexuosa in boreal forests. Can J Bot 82:430-435

Thompson K, Parkinson JA, Band SR, Spencer RE (1997) A comparative study of leaf nutrient concentrations in a regional herbaceous flora. New Phytol 136:679-689

Van Andel J (1975) A study on the population dynamics of the perennial plant species Chamaenerion angustifolium (L.) Scop. Oecologia 19:329-337

Van Andel J, Jager JC (1981) Analysis of growth and nutrition of six plant species of woodland clearings. J Ecol 69:871-882

Van Baalen J, Prins EGM (1983) Growth and reproduction of Digitalis purpurea in different stages of succession. Oecologia 58:84-91

Westoby M, Falster DS, Moles AT, Vesk PA, Wright IJ (2002) Plant ecological strategies: some leading dimensions of variation between species. Annu Rev Ecol Syst 33:125-159

Wilson PJ, Thompson K, Hodgson JG (1999) Specific leaf area and leaf dry matter content as alternative predictors of plant strategies. New Phytol 143:155-162

Yarie J (1980) The role of understory vegetation in the nutrient cycle of forested ecosystems in the mountain hemlock biogeoclimatic zone. Ecology 61:1498-1514

Zerbe S (1993) Fichtenforste als Ersatzgesellschaften von Hainsimsen-Buchenwäldern. Ber Forschungszentr Waldökosyst Reihe A, Bd 100, 173 pp 